\title{
GURU KONSTRUKTIVIS SISWAPUN KRITIS \\ (Studi Pustaka)
}

\author{
Oleh: \\ Muhammad Musfiatul Wardi
}

\section{A. PENDAHULUAN}

"Tidak ada Pelajaran yang Membosankan, tapi yang ada adalah Guru yang Membosankan"

Ungkapan diatas sangat singkat namun penuh makna, titik tekannya (streshing) terdapat pada kata-kata Guru membosankan. Guru merupakan salah satu faktor penting dalam proses pembelajaran, bila proses pembelajaran kualitasnya rendah secara otomatis hasilnya rendah begitupula sebaliknya. Ketika kualitas pendidikan rendah, masyarakat akan 'menghakimi' institusi pendidikannya, dan dalam institusi tersebut ada guru, dan biasanya guru 'disalahkan' karena tidak bisa mengajar (kurang berkualitas) meski belum tentu kebenarannya.

Penulis pernah membaca media, sebagian kalangan berpandangan bahwa pelaksanaan ujian semester bersama (USB), soal-soal ujiannya dibuat oleh dinas pendidikan. Para pengkritiknya menganggap USB belum tepat dilaksankan karena belum meratanya fasilitias pendidikan yang diberikan kepada sekolah, lebih-lebih sekolah swasta dan pinggiran. Dan yang berhak menilai perkembangan siswanya adalah guru yang berinteraksi langsung dengan siswanya, bukan dinilai dari 'kota' yang lengkap fasilitasnya terutama guru-gurunya. Meski dikritik, kepala dinas tersebut tidak bergeming dengan kebijakannya, dengan alasan USB selain berguna menilai kemampuan siswa, juga melihat kemampuan guru dalam mengajar. Ia mengatakan "Bila nilai siswa jelek, maka kualitas gurunya pun rendah".

Pernyataan tersebut bagi guru swasta dan pinggiran yang minim gaji dan fasilitas terasa begitu menyakitkan, karena mereka hanya memiliki modal dan semangat perjuangan demi anak bangsa. Ternyata kualitas mereka hanya dinilai 
dengan kemampuan siswa menjawab USB. Dan pemerintah tanpa memikirkan, bagaimana meningkatkan kualitas mereka. Kasus lain, dikalangan peserta didik (murid), sering terdengar mereka malas belajar bahkan tidak mau sekolah. Hal ini disebabkan, pelajaranya sulit. Selain itu, gurunya tidak bisa mengajar dan kadangkadang guru membuat tegang (kiler), sering marah.

Dari dua persoalan tersebut, guru seolah-olah dianggap sebagai biang terhambatnya kualitas pendidikan, meski tidak sepenuhnya demikian. Untuk itu, persoalan diatas sebaiknya dianggap sebagai kritikan bagi guru. Lalu untuk menjawab kritikan tersebut, sebaiknya guru merevolusi strategi dan metode pengjarannya dengan memahami salah satu filsafat konstruktivisme dalam pendidikan, karena konstruktivisme telah mempengaruhi kemajuan pendidikan di banyak Negara Amerika, Eropa dan Australia.

Di Indonesia, pemerintah mengaca pada kemajuan yang dicapai pendidikan barat telah membuat kebijakan kurikulum yang bernama Kurikulum Berbasis Komptensi (KBK) pada tahun 2004 dan sekarang dinamakan dengan Kurikulum Tingkat Satuan Pendidikan (KTSP). Meski kesannya agak telat, namun mau tidak mau harus diterapkan untuk mensejajarkan Indonesia dengan bangsa lain. KBK maupun KTSP memiliki ruh Konstruktivisme yang memberikan ruang sepenuhnya kepada peserta didik untuk mengekpresikan kemampuan yang mereka miliki dan guru menjadi mediator dan fasilitator siswa. Dalam tulisan ini, penulis memaparkan ruh dari KBK yaitu Konstruktivisme dan salah satu implikasinya dalam pembelajaran yaitu pembelajara bermakna (meaningful leraning). 


\section{B. PEMBAHASAN}

\section{a. Asal usul Konstruktivisme}

Konstruktivisme disebarkan oleh Jean Piaget, namun gagasan pokok konstruktivisme sudah dimulai oleh Giambatista Vico ${ }^{1}$, seorang epistemolog dari Italia. Dialah cikal bakal konstruktivisme.

Pada tahun 1710, Vico mengungkapkan filsafatnya dengan berkata, "Tuhan adalah pencipta alam semesta dan manusia adalah tuan dari ciptaan." Dia menjelaskan bahwa " mengetahui' berarti "mengetahui bagaimana membuat sesuatu." Hal ini berarti bahwa seorang dapat dikatakan tau ketika ia mampu menjelaskan unsure-unsur apa yang membangun sesuatu itu. Menurut Vico, hanya Tuhan sajalah yang dapat mengerti alam raya ini karena Dia yang tahu bagaimana membuatnya dan dari apa Ia membuatnya, sementara manusia hanya dapat mengetahui sesuatu yang telah dikonstruksikanNya. Bagi Vico, pengetahuan selalu menunjuk kepada struktur konsep yang dibentuk, menurutnya pengetahuan tidak lepas dari orang (subyek) yang tahu. Pengetahuan merupakan struktur konsep dari pengamat yang berlaku.

Piaget menuliskan gagasan konstruktivisme dalam teori tentang perkembangan kognitif yaitu, bahwa pengetahuan kita peroleh dari adaptasi struktur kognitif kita terhadap lingkungan, seperti suatu organisme harus beradaptasi dengan lingkungannya untuk melanjutkan kehidupan. ${ }^{2}$

Piaget adalah psikolog pertama yang menggunakan filsafat konstruktivisme dalam proses belajar. Ia menjelaskan bagaimana proses pengetahuan seseorang dalam teori perkembangan intlektual. Ia mengamati kehidupan keong, yang setiap kali harus beradaptasi dengan lingkungannya. Piaget mempercayai bahwa setiap mahluk hidup perlu beradaptasi dan mengorganisasi lingkungan sekitar agar tetap hidup sehingga pikiran dan tubuh juga mengikuti pola yang sama. Oleh karena itu,

\footnotetext{
${ }^{1}$ Paul Suparno, Filsafat Konstruktivisme dalam Pendidikan, (Yogyakarta : Kanisius 1997), hlm. 24 .

${ }^{2}$ Ibid, hlm. 25 .
} 
ia berfikir bahwa perkembangan pemikiran juga mirip dengan perkembangan biologis, yaitu perlu beradaptasi dengan dan mengorganisasi lingkungan sekitar. ${ }^{3}$

Proses teori konstruktivis Piaget berdasarkan tahapan-tahapan, pertama, Skemata/Skemata; skema adalah suatu struktur mental atau kognitif yang dengannya seorang secara intlektual beradaptasi dan mengkoordinasi lingkungan sekitarnya, misalnya bila anak pertama kali melihat kucing, maka ia akan membuat skema tentang kucing bahwa yang berkaki empat, bermata dua dan berbulu adalah kucing dan apabila ia melihat bintang lain seperti anjing misalnya, skema dalam pikirannya akan berkembang dan membuat perbedaan dan persamaan tentang kedua binatang yang telah dilihatnya. Sekema itu akan beradaptasi dan berubah selama perkembangan mental anak.

Kedua, Asimilasi; merupakan proses kognitif, dengannya seorang akan mengintegrasikan persepsi, konsep, atau pengalaman baru ke dalam skema atau pola yang sudah ada dalam pikirannya, setiap orang mengalami proses asimilasi secara terus-menerus. Misalnya orang sudah punya schemata tentang kucing yang berkaki empat dan bermata dua, dalam proses asimilasi, schemata tentang kucing diperluas dan diperinci lebih lengkap, bahwa kucing memiliki beraneka macam jenis. Dengan bahasa lain, asimilasi adalah salah satu proses individu dalam mengadaptasikan dan mengorganisasikan diri dengan lingkungan baru sehingga pengertian menjadi berkembang.

Ketiga, akomodasi adalah menyusun kembali struktur pikiran karena adanya informasi baru, sehingga informasi tersebut memiliki tempat, misalnya, seorang anak yang memiliki skema bahwa semua binatang memilki kaki empat, namun pada suatu ketika ia menemukan bintang yang memiliki kaki lebih dari empat, maka skema yang ia dapatkan tidak cocok lagi sehingga ia akan mengubah skema sebelumnya dengan mengadakan akomodasi yang membentuk skema baru. Schemata seorang dibentuk dengan pengalaman sepanjang waktu, schemata

\footnotetext{
${ }^{3}$ Ibid, hlm.30.
} 
menunjukkan menunjukkan taraf pengertian dan pengetahuan seorang tentang dunia di sekitarnya.

Keempat, Equilibration; dalam perkembangan intelektual seorang diperlukan keseimbangan antara asimilasi dan akomodasi proses itu disebut equilibrium, yakni pengaturan diri secara mekanis untuk mengatur keseimbangan antara asimilasi dan akomodasi. Equilibration membuat seorang dapat menyatukan pengalaman luar dengan struktur dalamnya (schemata).

\section{b. Konstruktivisme dalam Praktik}

Peran guru dalam pembelajaran menurut teori konstruktivisme adalah lebih sebagai fasilitator atau moderator ${ }^{4}$. Artinya guru bukan hanya sebagai sumber belajar yang harus ditiru ucapan dan tindakannya, sedang murid hanya sosok manusia yang bodoh, segala ucapan dan tindakannya tidak selalu dapat dipercaya atau salah. Proses pembelajaran cendrung menempatkan siswa sebagai sosok manusia yang pasif, statis dan tidak memilki kepekaan dalam menghadapi persoalaan. Sehingga dalam konstruktivisme, berfikir yang baik adalah lebih penting daripada menmpunyai jawaban yang benar atas suatu persoalan sedang terjadi ${ }^{5}$.

Seorang yang cara berfikirnya baik, akan dapat menemukann pemecahan dalam menghadapi persoalaan lain. Sementara itu, seorang pelajar yang hanya diarahkan untuk sekedar menemukan jawaban benar belum tentu dapat memecahkan persoalan yang baru karena tidak mengerti bagaimana cara menemukan jawaban itu.

Bila cara berfikir itu berdasarkan pengandaian yang salah atau tidak dapat diterima, siswa tersebut masih dapat memperkembangkannya. Mengajar dalam kontek konstruktivisme adalah membantu seorang berfikir secara benar dengan membiarkan siswa berpikir sendiri.

\footnotetext{
${ }^{4}$ Saekhan, Pembelajaran..., hlm.72.

5 Suparno, Filsafat...hlm. 65.
} 
Posisi siswa dalam pembelajaran menurut teori konstruktivisme adalah siswa harus aktif, kreatif dan kritis. Pembelajaran harus memberi ruang kebebasan kepada siswa mengelaborasi tentang apa yang diketahuinya dan mengemukakan ide-idenya tanpa kekangan dari guru. Siswa menurut kontruksivisme, dalam proses pembelajaran siswa harus aktif melakukan kegiatan, aktif berfikir, menyusun konsep dan memberi makna tentang hal-hal yang sedang dipelajari. Kontruktivistik memandang siswa sebagai pribadi yang sudah memiliki kemampuan awal sebelum mempelajari sesuatu, karena murid harus membangun sendiri pengetahuan mereka, seorang guru harus melihat murid bukan sebagai lembaran kertas putih kosong atau tabularasa. Pengetahuan awal yang mereka miliki adalah dasar untuk membangun pengetahuan selanjutnya.

Konstruktivisme merupakan pijakan untuk pembelajaran yang kontekstual, maka hal-hal yang berkaitan dengan pembelajaranpun paradigmanya berubah. Adapun hal-hal yang berkaitan pembelajaran tersebut ialah; Pertama, guru, dalam konstruktivistik guru berperan sebagai seorang yang berperan memberdayakan seluruh potensi siswa, agar siswa mampu melaksanakan proses pembelajaran. Guru bertugas tidak mentransferkan pengetahuan yang telah dimilikinya, melainkan berusaha memberdayakan seluruh potensi dan sarana yang dapat membantu siswa untuk membentuk pengetahuannya sendiri. Guru dituntut memilki kemampuan memahami jalan pikiran atau cara pandang siswa dalam belajar. Guru berfunsi sebagai motivator dan fasilitator dapat dijabarkan dalam beberapa tugas sebagai berikut. ${ }^{6}$

1. Menyediakan pengalaman belajar yang memungkinkan murid bertanggung jawab dalam membuat rancangan, proses, dan penelitian. Karena tugas utama guru bukan hanya memberi ceramah atau materi.

\footnotetext{
${ }^{6}$ Ibid, hlm. 66.
} 
2. Menyediakan atau memberikan kegiatan-kegiatan yang merangsang keingintahuan murid dan membantu mereka untuk mengekpresikan gagasan-gagasannya dan mengkomunikasikan ide mereka dan membangkitkan semangat mereka.

3. Memonitor, mengevaluasi, dan menunjukkan apakah pemikiran si murid jalan atau tidak. Guru menunjukkan dan mempertanyakan apakah pengetahuan murid itu berlaku untuk menghadapi persoalan baru yang berkaitan.

Kedua, sarana pembelajaran dan penguasaan bahan segala sarana baik perangkat keras maupun lunak harus didesain atau dikelola guru guna memperlancar proses pembelajaran. Sarana tidak hanya terbatas hanya sekolah saja, tapi juga bisa memanfaatkan yang ada di luar sekolah. Pembelajaran dalam kontek konstruktivistik harus menekankan penggunaan media sebagai satu-satunya sarana untuk mempercepat pemahaman terhadap materi, dengan sarana tersebut siswa akan berlatih untuk berfikir sendiri, memecahkan masalah yang dihadapinya, mandiri, kritis, kreatif dan mampu mempertanggungjawabkan pemikirannya secara rasional.

Peran guru sangat menuntut penguasaan bahan yang luas dan mendalam. Guru perlu mempunyai pandangan yang luas mengenai pengetahuan tentang bahan yang akan diajarkan. Pengetahuan yang luas dan mendalam memungkinkan seorang guru menerima pandangan dan gagasan yang berbeda dari murid dan juga memungkinkan untuk menunjukkan apakah gagasan itu jalan atau tidak. Penguasaan bahan memungkinkan seorang guru mengerti macam-macam jalan dan model untuk sampai pada suatu pemecahan persoalan tanpa terpaku pada satu model.

Ketiga, strategi mengajar, tugas guru adalah membantu agar siswa mampu mengkonstruksikan penegtahuannnya sesuai dengan situasinya yang kongkret maka strategi mengajar perlu juga disesuaikan dengan kebutuhan dan situasi murid. Oleh karena itu, tidak ada suatu strategi mengajar yang satu- 
satunya yang dapat digunakan dimana pun dan dalam situasi apa pun. Strategi yang disusun selalu hanya menjadi tawaran dan saran, bukan menu yang sudah jadi. Setiap guru yang baik akan memperkembangkan caranya sendiri.

Keempat, evaluasi pembelajaran, bentuk-bentuk evaluasi pembelajaran dalam teori konstruktivisme, diwujudkan melalui pemberian tugas-tugas autentik, mengkonstruksi pengetahuan yang dapat menggambarkan proses berfikir yang lebih tinggi.

Menurut Von Glaserfeld ${ }^{7}$, seorang guru tidak dapat mengevaluasi apa yang sedang dievaluasi, apa yang sedang dibuat murid atau apa yang mereka katakan. Yang harus dikerjakan guru adalah menunjukkan kepada murid bahwa yang mereka pikirkan itu tidak cocok atau tidak sesuai untuk persoalan yang dihadapi. Guru konstruktivis tidak menekankan kebenaran, tetapi berhasilnya proses pembelajaran. Pendekatan murid terhadap persoalan itu lebih penting daripada jawaban akhir yang digunakan.

Berikut skema, agar kita memahami pembelajaran konstruktif yang kita bandingkan dengan pembelajaran traditional $:^{8}$

\begin{tabular}{|l|l|}
\hline \multicolumn{2}{|c|}{ Perbandingan Pembelajaran konstruktivis dan Tradisional } \\
\hline Tradisional & Konstruktivis \\
\hline Kegiatan-kegiatanya bersandar pada textbook & $\begin{array}{l}\text { Kegiatan-kegiatannya bersandar pada materi } \\
\text { hand-on. }\end{array}$ \\
\hline $\begin{array}{l}\text { Presentasi materi dimulai dengan bagian-bagian, } \\
\text { kemudian pindah ke seluruhan. }\end{array}$ & $\begin{array}{l}\text { Presentasi dimulai dengan keseluruhan, } \\
\text { kemudian ke bagian-bagian. }\end{array}$ \\
\hline $\begin{array}{l}\text { Menekankan pada keterampilan-keterampilan } \\
\text { dasar }\end{array}$ & Menekankan pad aide-ide besar \\
\hline $\begin{array}{l}\text { Guru menekankan tentang harus diikutinya } \\
\text { kurikulum yang pasti }\end{array}$ & Guru mengikuti pertanyaan-pertanyaan murid \\
\hline
\end{tabular}

\footnotetext{
${ }^{7}$ Ibid, hlm. 70.

${ }^{8}$ Daniel Muijs dan David Reynolds, Efective teaching Teori dan Aplikasi, terj, (Yogyakarta : Pustaka Pelajar, cet I,2008),hlm.105
} 


\begin{tabular}{|l|lr|}
\hline Guru mempersentasikan informasi kepada murid & $\begin{array}{l}\text { Guru menyiapkan lingkungan belajar, dimana } \\
\text { murid dapat menemukan pengetahuan }\end{array}$ \\
\hline $\begin{array}{l}\text { Guru berusaha membuat murid memberikan } \\
\text { jawaban yang benar }\end{array}$ & $\begin{array}{l}\text { Guru berusaha membuat murid } \\
\text { mengungkapakan sudut pndang dan } \\
\text { pemahaman mereka dapat memahami } \\
\text { pembelajaran mereka. }\end{array}$ \\
\hline $\begin{array}{l}\text { Asesmen dilihat sebagai sebuah kegiatan } \\
\text { tersendiri, dan terjadi melalui testing. }\end{array}$ & $\begin{array}{l}\text { Asesmen dilihat sebagai sebuah kegiatan yang } \\
\text { di integrasikan dengan belajar-mengajar, dan } \\
\text { terjadi melalui fortofolio dan observasi. }\end{array}$ \\
& \\
\hline
\end{tabular}

\section{c. Hubungan Guru dan Murid.}

Dalam aliran konstruktivisme, guru bukanlah seorang yang maha tahu dan murid bukanlah yang belum tahu dan karena itu harus diberi tahu. Atau dalam bahasa pakar pendidikan, guru adalah subjek dan peserta didik adalah objek. ${ }^{9}$ Dalam proses pembelajaran murid aktif mencari tahu, sedangkan guru membantu agar proses pencaritahuan berjalan dengan baik. Artinya hubungan guru dan murid lebih sebagai mitra yang bersama-sama membangun pengetahuan.

Guru dalam melaksanakan pembelajaran perlu memiliki pengetahuan psikologi. Kemampuan memahami tingkah laku peserta didiknya akan member penjelasan bahwa peserta didik sedang dalam keadaan belajar dengan baik atau tidak dan dengan pemahaman ini guru dapat mengukur kemampuan belajar peserta didik serta kemampuan menerima materi yang disampaikan. ${ }^{10}$

${ }^{9}$ Abdurrahman, Meaningful Learning; Re-invensi Kebermaknaan Pembelajaran, (Yogyakarta : Pustaka Pelajar, Cet. 1, 2007), hlm. 7.

${ }^{10}$ Syaiful Sagala, Konsep dan Makna Pembelajaran, (Bandung : ALFABETA, 2010), hlm. 133. 


\section{PEMBELAJARAN BERMAKNA (Meaningful learning)}

Pembelajaran ${ }^{11}$ pada hakekatnya adalah suatu proses interaksi antar peserta didik dengan guru, peserta didik dengan peserta didik, peserta didik dengan sumber belajar. Kegiatan pembelajaran ini akan menjadi bermakna bagi peserta didik jika dilakukan dalam lingkungan yang nyaman dan memberikan rasa aman bagi anak. Proses belajar bersifat individual dan kontekstual, artinya proses belajar terjadi dalam diri individu sesuai dengan perkembangannya dan lingkungannya.

Berkaitan dengan peserta didik (siswa) dengan lingkungan belajarnya menurut pandangan konstruksivisme, mengajukan karakteristik sebagai berikut :

1. Siswa tidak dipandang sebagai sesuatu yang pasif melainkan memiliki tujuan.

2. Belajar mempertimbangkan seoptimal mungkin proses keterlibatan siswa.

3. Pengetahuan bukan sesuatu yang datang dari luar melainkan dikonstruksi secara personal,

4. Pembelajaran bukanlah transmisi pengetahuan, melainkan melibatkan pengetahuan situasi kelas,

Kurikulum bukanlah sekedar dipelajari melainkan seperamgkat pembelajaran, materi, dan sumber. ${ }^{12}$

Ada empat pilar pembelajaran untuk menghadapi dan menyesuaikan diri dengan tuntutan perkembangan dunia yang sangat cepat, empat pilar tersebut yaitu : belajar mengetahuai (learning to know), belajar berkarya (learning to do), belajar hidup bersama (learning to live together) dan belajar berkembang secara

${ }^{11}$ Pembelajaran sebagai suatu system atau membelajarkan peserta didik yang direncanakan, dilaksanakan, dan dievaluasi secara sistematis agar pembelajaran dapat mencapai tujuan pembelajaran secara aktif, efektif, dan inovatif. Lihat, Udin Syaefudin Sa'ud, Inovasi Pendidikan, (Bandung, ALFABETA, 2009), hlm. 124.

${ }^{12}$ Sofan Amri \& Iif Khoiru Ahmadi, Konstruksi Pengembangan Pembelajaran; Pengaruhnya Terhadap Mekanisme dan Praktik Kurikulum, (Jakarta : Prestasi Pustaka, Cet. 1, 2010), hlm. 145 146. 
utuh (learning to be). ${ }^{13}$ Menurut Ausubel, belajar bermakna adalah suatu proses belajar di mana informasi baru dihubungkan dengan struktur pengertian yang sudah dimiliki seseorang yang sedang belajar. ${ }^{14}$

Empat pilar tersebut apabila dikonstruk dalam pemebelajaran maka pembelajaran akan menjadi bermakna bagi peserta didik.

Belajar bermakna (meaningful leraning) terjadi bila peserta didik menghubungkan pengetahuannya dengan persoalan-persoalan yang berada di sekitarnya, sehingga mereka akan merasakan bagaimana pentingnya mereka dan pengetahuannya terhadap lingkungan sosial, sehingga peserta didik akan selalu peka terhadap persoalan yang ada. Hal ini akan terwujud melalui belajar konsep, dan perubahan konsep yang telah ada, akan mengakibatkan pertumbuhan dan perubahan struktur konsep yang telah dimiliki oleh peserta didik. Sebagaimana yang diungkapkan Ausubel; seorang belajar dengan mengasosiasikan fenomena baru ke dalam skema yang telah ia miliki sebelumnya. Dalam proses belajar ini siswa mengkonstruksi apa yang ia pelajari sendiri. ${ }^{15}$

Pembelajaran bermakna (meaningfull learning) merupakan suatu proses dikaitkannya informasi baru pada konsep-konsep relevan yang terdapat dalam struktur kognitif seseorang. Pembelajaran bermakna sebagai hasil dari peristiwa mengajar ditandai oleh terjadinya hubungan antara aspek-aspek, konsep-konsep, informasi atau situasi baru dengan komponen-komponen yang relevan di dalam struktur kognitif siswa. Proses belajar tidak sekadar menghafal konsep-konsep atau fakta-fakta belaka, tetapi merupakan kegiatan menghubungkan konsepkonsep untuk menghasilkan pemahaman yang utuh, sehingga konsep yang dipelajari akan dipahami secara baik dan tidak mudah dilupakan. Dengan demikian, agar terjadi belajar bermakna maka guru harus selalu berusaha mengetahui dan menggali konsep-konsep yang telah dimiliki peserta didik dan

\footnotetext{
${ }^{13}$ Ibid., hlm. 151.

${ }^{14}$ Suparno, Filsafat.... hlm.54

${ }^{15}$ Ibid.,
} 
membantu memadukannya secara harmonis konsep-konsep tersebut dengan pengetahuan baru yang akan diajarkan.

Dengan kata lain, belajar menjadi lebih bermakna jika anak mengalami langsung apa yang dipelajarinya dengan mengaktifkan lebih banyak indera daripada hanya mendengarkan orang/guru menjelaskan. Contoh, Untuk menjelaskan tentang belajar bermakna ini, perhatikan tiga bilangan berikut. Dari tiga bilangan berikut:

(a) 50.471 .198

(b) 54.918 .071

(c) 17.081 .945

Manakah yang lebih mudah dipelajari atau diingat para siswa? Seorang siswa dapat saja mengingat ketiga bilangan tersebut yaitu dengan mengucapkan bilangan tersebut berulang-ulang beberapa kali. Namun sebagai warga bangsa Indonesia tentunya kita akan meyakini bahwa bilangan (c) yaitu 17.081.945 merupakan bilangan yang paling mudah dipelajari jika bilangan tersebut dikaitkan dengan tanggal 17 - 08 - 1945 yang merupakan hari kemerdekaan Republik Indonesia. ${ }^{16}$

Proses pembelajaran bilangan 17.081.945 (tujuh belas juta delapan puluh satu ribu sembilan ratus empat puluh lima) akan bermakna bagi siswa hanya jika si siswa, dengan bantuan gurunya, dapat mengaitkannya dengan tanggal keramat 17 Agustus 1945 yang sudah ada di dalam kerangka kognitifnya. Bilangan (b) yaitu 54.918.071 akan lebih mudah dipelajari siswa daripada bilangan (a) yaitu 50.471.198 karena bilangan (b) didapat dari tanggal 17-08-1945 dalam urutan terbalik yaitu 5491-80-71. Bilangan (a) merupakan bilangan yang paling sulit untuk dipelajari karena aturan atau polanya belum diketahui.

\footnotetext{
${ }^{16}$ Kafe Guru Blog di akses 22 januari 2011 jam 22 : 09
} 
Contoh di atas menunjukkan bahwa suatu proses pembelajaran akan lebih mudah dipelajari dan dipahami siswa jika para guru mampu dalam memberi kemudahan bagi siswanya sedemikian sehingga para siswa dapat mengaitkan pengetahuan yang baru dengan pengetahuan yang sudah dimilikinya. Itulah inti dari belajar bermakna (meaningful learning) yang telah digagas David $\mathrm{P}$ Ausubel.

Di Indonesia, salah satu sekolah yang menurut penulis menerapkan pembelajaran bermakna (meaningful leraning) adalah SMP Alternatif Qaryah Thayyibah, Qaryah Thayyibah lahir dari keprihatinan pendirinya Baharuddin melihat pendidikan Indonesia yang buruk dan mahal. Bahruddin mengadopsi kurikulum SMP regular di sekolahnya, karena Ia tidak mampu menyusun kurikulum sendiri. Lagi pula, sekolah akan diakui berkualitas jika bisa memperoleh nilai yang baik dan mendapatkan ijazah yang diakui karena itulah ia memilih format SMP terbuka. Akan tetapi ia mengubah kecendrungan SMP terbuka sebagai lembaga untuk membagi-bagi ijazah dengan mengelola pendidikan secara serius, jumlah guru yang mengajar Sembilan orang, semuanya lulusan IAIN. Akses internet gratis 24 jam diperoleh dari seorang pengusaha internet di Salatiga yang tertarik dengan gagasan Bahruddin, dengan modal seadanya sekolah itu dioperasionalkan. ${ }^{17}$ Dan hasilnya cukup memuaskan, bahkan mampu mengimbangi sekolah-sekolah negeri di Salatiga, sekolah ini juga mewakili Salatiga dalam Konvesi Lingkungan Hidup pemuda Asia Pasifik di Surabaya. Qaryah Thaiyabah berhasil juga dalam dunia seni, kendati baru didirikan. Ternyata, keseriusan memabawa hasil.

Di SMP Qaryah Thayyibah, pembelajaran dimulai pada pukul 06.00 dan berakhir pada pukul 13.30. namun karena belajar bagi siswa SMP Qaryah Thayyibah sangat menyenangkan, seusai makan siang di rumahnya, para siswa biasanya kembali ke sekolah. Karena di sekolah mereka bisa bermain, membuka

17 Bahruddin, Pendidikan Alternatif Qaryah Thayyibah, (Yogyakarta : LKIS, cet I, Januari) hlm.29. 
internet, berdiskusi dengan guru maupun berlatih musik. Sekolah tidak pernah tutup, tidak jarang siswa berada di sekolah hingga larut malam bahkan menginap di sekolah. ${ }^{18}$

Bersekolah bukanlah sebuah beban bagi siswa SMP Qaryah Thayyibah tapi suatu yang sangat menyenangkan. Di sekolah mereka bisa belajar sambil bermain. Di sekolah, mereka bisa mengerjakan soal-soal fisika yang rumit sambil mendengarkan musik, mereka bebas duduk pakai kursi atau lesehan tapi tetap belajar.

Penulis pernah menerapkan konstruktivisme ketika menjadi pendidik di sekolah swasta daerah terpencil kendati tidak seperti SMP Qaryah Thayyibah, pada saat itu, penulis belum mengetahui apa yang kami lakukan merupakan konstruktivisme. Kami merintis sebuah sekolah di tengah hutan yang termasuk dalam kawasan Taman Nasional Gunung Rinjani (TNGR), sekolah ini berdiri karena dari 40 anak yang tamat SMP (sekolah SMP swasta, yang hanya satusatunya sekolah lanjutan di kawasan tersebut) hanya 5 orang saja yang dapat melanjutkan ke jenjang menengah, sisanya kawin, 'nganggur' dan menjadi TKI. Atas dasar inilah sekolah setingkat SMU kami dirikan. Pada awalnya (2009), sekolah ini berjalan apa adanya, siswa pertama sekitar 30 orang, dan guru mata pelajaran terkadang memegang 3 mata pelajaran, guru-guru jarang yang mau mengajar di sekolah tersebut karena lokasinya cukup jauh dan gaji sangat minim, tergantung dari kemampuan masyarakat. Untuk mensiasati kekurangan guru tersebut, siswa-siswa sejak awal kami perkenalkan dengan masalah-masalah lingkungan sosial mereka, dan mereka mencoba menyelseikannya bersama-sama.

Setiap malam Jum'at, diwajibkan bagi siswa menginap di sekolah untuk membaca yasinan, setelah yasinan masing-masing kelompok mempresentasikan tentang permasalahan-permasalahan yang mereka temukan di lingkungan mereka, dari hasil diskusi mereka, terbentuklah program kerja harian, mingguan

Ibid, hlm.155 
dan bulanan yang mereka buat sendiri dan melaksankannya dengan aturan-aturan yang telah disepakati oleh mereka, sedangkan kami sebagai pendidik hanya memberi motifasi dan mendampingi kegiatan mereka. Salah satu program harian mereka misalnya, sekolah masuk pukul 07.00, namun guru datang jam 09.00 karena rumah guru jauh akibatnya jam pertama biasanya mereka nganggur. Untuk menyelseikan permaslahan itu, kami memberikan penjelasan dan memaklumi kondisi ini, akhirnya mereka berdiskusi menyelseikan masalah ini, dengan membuat program harian shalat Duha berjama'ah dan berpidato menunggu guru datang. Selain itu juga, mereka mewajibkan diri mereka menulis diari setiap hari.

Saat ini, mereka sudah belajar menulis makalah. Setiap persoalan yang mereka temukan di lingkungannya, mereka membuat tulisan sederhana. Dan mereka tidak sungkan berdebat dengan temannya bahkan kritis terhadap apa yang disampaikan guru mereka. Dengan hasil tersebut, kami sebagai pendidik sedang berusaha mencari buku-buku bacaan sebagai literature mereka dalam menulis makalah dan lain-lain. Minat baca mereka sudah terbangun, setiap buku yang kami berikan, mereka berebutan untuk membacanya lebih awal. namun buku-buku bacaan yang mereka miliki masih minim akibat keterbatasan financial. Dengan menghubungkan problem lingkungan dalam pembelajaran ternyata membuat siswa senang dan bersemanagat menyelseikan persoalan masyarakatnya, semoga yang kami lakukan dinamakan meaningful learning.

\section{SIMPULAN}

Konstruktsivisme telah banyak mempengaruhi kemajuan kualitas pendidikan di banyak Negara Amerika, Eropa dan Australia. Dapat kita lihat saat ini, Barat dapat mendominasi ilmu pengetahuan dan teknologi. Apa yang menyebabkan Barat maju? Salah satunya menurut ialah dengan memajukan pendidikan yang dalam system pembelajarannya menggunakan prinsip-prinsi konstruktivisme yaitu (1) pengetahuan dibangun oleh siswa sendiri, baik secara personal maupun social, (2) pengetahuan tidak dapat dipindahkan dari guru ke 
murid, kecuali hanya dengan keaktifan murid sendiri untuk menalar (3) murid aktif mengkonstruksi terus menerus, sehingga selalu terjadi perubahan konsep menuju ke konsep yang lebih rinci, lengkap serta sesuai dengan konsep ilmiah (4) guru sekedar membantu menyediakan sarana dan situasi agar konstruksi siswa berjalan dengan baik.

Konstruktivisme mempengaruhi teori belajar, salah satunya Teori Belajar Bermakna (meaningful learning)yang dikemukakan oleh Ausubel. Dimana teori ini menekankan pentingnya asimilasi pengalaman baru ke dalam konsep atau pengertian yang telah dimiliki siswa, sehinga siswa dalam proses belajar itu siswa aktif. Salah satu contoh sekolah yang menurut penulis telah menerapkan konstruktivisme dalam pembelajarannya ialah SMP alternative Qaryah Thayyibah yang berada di Desa Kalibening kota Salatiga Jawa Tengah. Meski terletak dipinggiran, sekolah ini telah mampu berprestasi bahkan mengalahkan sekolah-sekolah Negeri yang telah lama berdiri.

\section{DAFTAR PUSTAKA}

Abdurrahman, Meaningful Learning; Re-invensi Kebermaknaan Pembelajaran, (Yogyakarta : Pustaka Pelajar, Cet. 1, 2007) I, Januari).

Bahruddin, Pendidikan Alternatif Qaryah Thayyibah, (Yogyakarta : LKIS, cet

Daniel Muijs dan David Reynolds, Efective teaching Teori dan Aplikasi, terj, (Yogyakarta : Pustaka Pelajar, cet I,2008)

M. Saekhan Muchit, Pembelajaran Kontekstual (Semarang : Rasail media group, cet.I, 2008).

Paul Suparno, Filsafat Konstruktivisme dalam Pendidikan, (Yogyakarta : Kanisius 1997). 2010).

Syaiful Sagala, Konsep dan Makna Pembelajaran, (Bandung : ALFABETA, 
Sofan Amri \& Iif Khoiru Ahmadi, Konstruksi Pengembangan Pembelajaran; Pengaruhnya Terhadap Mekanisme dan Praktik Kurikulum, (Jakarta : Prestasi Pustaka, Cet. 1, 2010)

Udin Syaefudin Sa’ud, Inovasi Pendidikan, (Bandung, ALFABETA, 2009). 